\title{
Self-regulated learning behavior and perception of students participating in EU- SUPPORT social network
}

\author{
S. Charoenwet ${ }^{1}$ I. Zurida ${ }^{2}$ \\ ${ }^{1}$ Suratpittaya School Surat Thani 84000 Thailand salubsri@gmail.com \\ ${ }^{2}$ University Sains Malaysia Penang Malaysia zurida@usm.my
}

\begin{abstract}
A student collaborative social network was established based on computer-supported collaborative learning (CSCL) platform of EUSUPPORT network. The EU-SUPPORT is a sub network under the Norwegian Environmental Education that focuses on schools to promote the quality of education for sustainable development. Participants were two hundred of students from secondary schools in Malaysia and Thailand who engaged in task-based discussion forum related to environmental issues. Students collaboratively worked on assigned online activities with the theme 'Climate Change' via web-based instructions. Selfreported survey questionnaires were administered prior and after the activities in order to investigate, self-regulated learning behaviors and students' perception towards the learning platform. The results from questionnaire statistical analysis revealed that collaborative learning activities significantly improved self-regulated learning behaviors of students participating in this social network. The analysis of students' perception indicated that students tended to have positive feeling towards the learning environment.
\end{abstract}

Keywords: CSCL, collaborative learning, EUSUPPORT, social network, self-regulated learning, students' perception

\section{INTRODUCTION}

The development of advanced information and communication technologies (ICT) has led to computer application in education such as e-mail, chat room, video conference and discussion forum. These technologies become potentially useful tools to enhance effective learning environment for students while the benefits of ICT in moderating positive effects on students' learning have also been regularly reported [1].

A new concept of learning is recognized by researchers and theorists that learning is not only cognitive but also a social cultural and interpersonal constructive process [2]. Hence, instructional strategies such as collaborative learning are increasingly used in educational setting in order to create interaction among students for such learning environment. In collaborative learning environment, students work together in group, exchange ideas and share experiences in order to achieve particular solutions to complex problems and, hence build up knowledge. Positive effects of collaborative learning have been well documented by researchers that it enhances students' cognitive performance and stimulates students to engage in knowledge construction [3].

A combination of ICT application and collaborative learning results in a new field of educational design; computer-supported collaborative learning (CSCL) which deals with issues concerning collaboration, learning processes, and the use of computer-mediated communication (CMC). The primary aim of CSCL is to provide an environment that supports collaboration between students and enhance learning processes [4]. CSCL usually offers tools that facilitate sharing of information and ideas, and the distribution of expertise among group members [5]. When students collaborate in a CSCL environment, they use computer-mediated communication- $\mathrm{CMC}$ to communicate with group members in form of synchronous; a chat facility and video conferencing, or asynchronous; a discussion forum and e-mail.

Research in CSCL has gained considerable attention in recent years while implementing of CSCL in educational setting has been increasingly paid attention to. Research findings indicate that CSCL environments offer a medium for classroom discussion that possibly facilitates participation and social interaction among students, hence providing more effective interaction and participation than in the traditional classroom setting [5]. Several studies have reported the benefits of CSCL in facilitating task oriented and reflective activity [6], complex reasoning and argumentation [7], critical thinking [8] and authentic proof activity [9].

However, effective learning environment of CSCL requires particular online learning behaviors for successful outcomes. In general, online learning environment needs more learner control and self direction as the situation represents higher level of intellectual development [10]. In addition, providing learners with control of their own learning, it is recommended that self-regulated behaviors are essentially required [11]. 
This study reports results of the investigation into CSCL setting under EU-SUPPORT network and its effect on self-regulated learning behaviors and perception of students participating in the network activities. Self-regulated learning behaviors and students' perception are examined through selfreported survey questionnaires.

\section{MATERIALS AND METHODS}

\section{Participants and setting}

Two hundred students from secondary schools in Thailand and Malaysia took part as distributed learners in this network through collaborative webbased project along with other network members from schools around the globe. The main activity of the project was the International Campaign of $\mathrm{CO}_{2}$ on the way to school. The resources and instructions of project activities were available on the website of co2connect and communication among participants was facilitated through webbased instruction under EU-SUPPORT network system. While students are engaged in learning activities, the development of social network is monitored through participation and interaction among participants. Data stored in log files of the server database system was later retrieved to use for data analysis.

\section{Procedure and task}

Schools participating in the project were required to sign up for membership on the website: http:///www.co2nnect.org which was established under EU-SUPPORT program. Students taking part in the co2connect campaign were allowed to login and enter information of how they travelled to school and the distance on co2connect website. The amount of $\mathrm{CO}_{2}$ was automatically computed and available for students to view. Data from all locations of schools that had taken part in this project was pooled, shared compared along with collaborative activities regarding the obtained information. Discussion forum for climate ideas was initially established to exchange ideas among participants for possible solutions, based on local context.

During the co2connect campaign, students were encouraged to carry out other related project activities concerning reducing the amount of $\mathrm{CO}_{2}$ both in classes and between schools. The outcomes of project activities were uploaded to share for constructive comments. Basically, climate ideas posted in discussion forum represented were groups' ideas. The campaign lasted for two weeks then related activities were continually carried on for another four weeks. Prior to the beginning of the campaign students were asked to complete self regulated learning behavior questionnaires. These questionnaires were also distributed along with students' attitude questionnaires by the end of network co2connect campaign activities.

\section{Measure and Data analysis}

Two self-reported survey questionnaires; selfregulatory learning questionnaires and students' attitudes questionnaires with 5-points Likert scale were used to examine learning behaviors and students' perception. Self-regulated learning questionnaires consisted of 23 items in six dimensions, adapted from previous study of Barnard et al. [12] with internal consistency reliability of Cronbach $\alpha 0.90$. Students' attitude questionnaires consisted of 23 items in four dimensions adapted from the studies of Tseng, Chiang, \& Hsu, (2008), Liaw et al. [13] with Cronbach $\alpha 0.93$. Pretest and posttest results from self-regulated learning behavior questionnaires and the posttest of students' attitude questionnaires were quantitatively analyzed using SPSS version 16 software.

\section{RESULTS}

Table 1 Mean score on pretest and posttest for selfregulated learning behaviors

\begin{tabular}{|c|c|c|c|c|}
\hline \multirow{2}{*}{ Group } & \multicolumn{2}{|c|}{ Pretest } & \multicolumn{2}{c|}{ Posttest } \\
\cline { 2 - 5 } & Mean & SD & Mean & SD \\
\hline Thailand & 3.25 & 0.47 & 3.85 & 0.28 \\
Malaysia & 3.44 & 0.53 & 3.63 & 0.50 \\
\hline Mean & 3.35 & 0.51 & 3.74 & 0.42 \\
\hline
\end{tabular}

Table 2 Mean score and standard deviation on the pretest and posttest for self-regulated learning behaviors in six dimensions

\begin{tabular}{|l|c|c|c|c|}
\hline \multirow{2}{*}{ Dimensions } & \multicolumn{2}{|c|}{ Pretest } & \multicolumn{2}{c|}{ Posttest } \\
\cline { 2 - 5 } & Mean & SD & Mean & SD \\
\hline 1.Goal setting & 3.35 & 0.62 & 3.77 & 0.50 \\
2.Environmental & 3.64 & 0.66 & 3.95 & 0.54 \\
$\begin{array}{l}\text { structuring } \\
\text { 3.Task } \\
\text { strategies }\end{array}$ & 3.00 & 0.77 & 3.55 & 0.58 \\
$\begin{array}{l}\text { 4.Time } \\
\text { management }\end{array}$ & 3.21 & 0.82 & 3.61 & 0.70 \\
$\begin{array}{l}\text { 5.Help seeking } \\
\text { 6. Self } \\
\text { evaluation }\end{array}$ & 3.26 & 0.82 & 3.65 & 0.65 \\
\hline
\end{tabular}

The results from paired sample t-test of SPSS analysis show that posttest mean score of selfregulated learning behaviors is significantly higher than pretest mean score $t(199)=17.40, p<0.05$ with the mean score of pretest and posttest of 3.35 $(S D=0.51)$ and $3.74 \quad(S D=0.42)$ respectively. Further t-test analysis for each dimension was carried out to ensure the difference. It is found that there is a statistically significant increase of mean scores in all dimensions; Goal setting $t(199)=15.27$, $p<0.05$, Environmental structuring $t(199)=12.92$, $p<0.05$, Task strategies $t(199)=16.22, p<0.05$, Time 
management $t(199)=12.65, p<0.05$, Help seeking $t(199)=13.69, \quad p<0.05$ and Self evaluation $t(199)=12.34, p<0.05$.

Table 3 Mean score and standard deviation for students' perception in four dimensions

\begin{tabular}{|l|c|c|c|c|}
\hline \multirow{2}{*}{ Dimensions } & \multicolumn{2}{|c|}{ Thailand } & \multicolumn{2}{c|}{ Malaysia } \\
\cline { 2 - 5 } & Mean & SD & Mean & SD \\
\hline $\begin{array}{l}\text { 1. Learning } \\
\text { platform }\end{array}$ & 3.60 & 0.59 & 3.58 & 0.58 \\
$\begin{array}{l}\text { 2. Interaction } \\
\begin{array}{l}\text { 3.Communication } \\
\text { \& collaboration }\end{array}\end{array}$ & 3.71 & 0.51 & 3.55 & 0.64 \\
$\begin{array}{l}\text { 4. Learning } \\
\text { environment }\end{array}$ & 3.63 & 0.54 & 3.56 & 0.74 \\
\hline Mean & 3.60 & 0.45 & 3.54 & 0.52 \\
\hline
\end{tabular}

Over all mean score of students' perception from both studied group, Thailand and Malaysia are 3.60 $(S D=0.45)$ and $3.54(S D=0.21)$ respectively. The results from independent sample t-test analysis shows that there is no statistically difference between mean score of students' perception between the two groups $t(198)=0.86, p>0.05$. Independent sample t-test analysis of the four dimensions also shows that there is no significant difference in the mean score of students' perception in Learning platform $t(198)=0.17, \quad p>0.05$, Communication and collaboration $t(198)=0.13$, $p>0.05$ and Learning environment $t(198)=0.73$, $p>0.05$. However, there is a significant difference in Interaction $t(198)=1.98, p<0.05$.

\section{DISCUSSION}

The results of learning behaviors from this study imply that collaborative learning environment in the social network supported by CSCL system has positive influence on self-regulated learning of students participating in network activities. It has been reported that students that study in the learning environments based on communication and information technology are obliged to use more self-regulated strategies in facing with computer based learning and coordinate themselves with their learning environments [14, 15]. SRL is initially developed as interaction of personal, behavioral and environmental factors [16] and usually occurs when students are motivated to strategically engage in learning activities within environments that foster self-regulation [17]. Learning process in this social network is, therefore assumed to provide enriched environment for students to reinforce selfregulatory skills while engaging in the collaborative learning activities. It is indicated that SRL concerns the application of general models of regulation and self-regulation of cognition, motivation behavior, and context to issues of learning [18]. Besides SRL is associated with academic achievement [12], it is possible to claim that students who have reflectively developed SRL skills are likely to be more successful in learning. Therefore it is recommended that designing learning environment to encourage SRL behavior is likely to result in effective learning. However, further researches are required to investigate into this aspect.

Apparently, students from studied groups perceive CSCL learning platform in the social network similarly with positive effect though not in all dimensions. Overall mean score of students' attitudes web-based problem based learning platform in a study conducted by Tseng et al. [19] is 3.89. Generally students' attitudes obtained from students participating in learning activities in this study, is considered satisfying. There is an evidence indicates that students' perception toward online course is associated with self-regulated learning [12]. In addition, a study of Karoly [20] demonstrates that students who are highly selfregulated tend to engage in their learning more, perform better, compared to those who are less self-regulated and hence have positive perception.

Another reason that possibly leads to positive effect students' perception in this study is due to the features of friendly human-computer interface and well-established network system with actively updated information. These features of the webpage are in accordance with TAM-Technology Accepted Model and hence cause perceive of usefulness among users [21]. Besides, the activities that are practically realistic and related to current issue i.e. global warming also result in encouraging students to actively participate and collaborate in the network. The social network successfully created enriched learning environment and helped students develop and apply SRL behaviors in their learning [22].

In summary, the investigation into student social network under EU-SUPPORT provides initial information about nature of the network and its effect on SRL learning behaviors and students' perception in some extent. Although the learning process in this network is apparently group collaboration as a whole, the effectiveness of collaborative process resulted from enriched learning environment is apparently observed in an individual through learning behaviors and attitudes. It is clearly seen that students in learning environment such as CSCL setting are potentially encouraged to build up self-regulated learning behavior and so help students to learning efficiently. Further studies are essential to reveal more about the effect of social interaction in other aspects in order that the effectiveness of learning process in CSCL environment is established. 


\section{REFERENCES}

[1] C. Fletcher-Flinn and B. Gravatt, "The efficacy of computer assisted instruction (CAI): a meta-analysis", Journal of Educational Computing Research, pp.219-241, 1995.

[2] G. Salomon and D. Perkins, "Individual and social aspects of learning", Review of research in education, pp. 1-24, 1998.

[3] G. Stahl, "Building collaborative knowing: Elements of a social theory of CSCL", What we know about CSCL, and implementing it in higher education?, pp. 53-85, 2004.

[4] K., Kreijns , P. Kirschner, and W. Jochems, "Identifying the pitfalls for social interaction in computer- supported collaborative learning environments: a review of the research", Computers in Human Behavior, pp. 335-353, 2003.

[5] L. Lipponen, M. Rahikainn, J. Lallimo and K. Hakkarainen, "Patterns of participation and discourse in elementary students' computer-supported collaborative learning", Learning and Instruction, pp. 487-509, 2003

[6] A. Cohen and M. Scardamalia, "Discourse about ideas: monitoring and regulating in face-to-face and computermediated environments", Interactive Learning Environments, pp.93113,1998 .

[7] C. Hoadley and M. Linn, "Teaching science through online peer discussions: speakeasy in the knowledge integration environment", Journal of Science Teaching, pp.839-857, 2000.

[8] J. Yukawa, "Co-reflection in online learning: Collaborative critical thinking as narrative" International Journal of Computer-Supported Collaborative Learning, pp.203-228, 2006.

[9] D. Öner, "Supporting students' participation in authentic proof activities in computer supported collaborative learning (CSCL) environments", International Journal of ComputerSupported Collaborative Learning, pp.343-359, 2008.

[10] P. Bell, "Predictors of college student achievement in undergraduate asynchronous web-based courses" Education, pp.523-533, 2007.

[11] J. Young, "The effect of self-regulated learning strategies on performance in learner controlled computer-based instruction", Educational Technology Research and Development, pp.17-27, 1996.
[12] L. Barnard, V. Paton and W. Lan, "Online self-regulatory learning behaviors as a mediator in the relationship between online course perceptions with achievement", International Review of Research in Open \& Distance Learning, pp.1-11, 2008.

[13] S. Liaw, H. Huang, and G. Chen, "Surveying instructor and learner attitudes toward e-learning", Computer \& Education, pp.1066-1080, 2007.

[14] Esmaeel Pour Moghadam , H.R. \& Jaafari Roshan, M. (2013) Relationship between epistemologicalbeliefs and self-regulated learning in high schools students of traditional and smart schools. Retrieved May 15, 2013, from http://www.joursa.com

[15] Bråten, I. (2010). Personal epistemology in education: Concepts, issues, and implications. Retrieved May 12, 2013, from http://www. uv.uio.no/pfi/english/people/aca/ivarbr

[16] B. Zimmerman and D. Schunk, Selfregulated learning and academic achievement: Theoretical perspectives, 2001.

[17] H. Patrick and M. Middleton, "Turning the kaleidoscope: What we see when self-regulated learning is viewed with a qualitative lens", pp.27-39, 2002.

[18] Philip H. W. \& Allyson F. H. (2013) nStudy: Tracing and Supporting Self-Regulated Learning in the Internet. Retrieved May 15, 2013, from http://link.springer.com/ chapter/10.1007/978-1-4419-5546-3_20

[19] K. Tseng, F. Chiang and W. Hsu, "Interactive processes and learning attitudes in a web-based problem-based learning (PBL) platform", Computers in Human Behavior, pp. 940-955, 2008.

[20] P. Karoly, "Mechanisms of selfregulation: A systems view", Annual Review of Psychology, pp. 23-52, 1993.

[21] F. Davis, R. Bagozzi and P. Warsaw, "User acceptance of computer technology: a comparison of two theoretical models" Management Science, pp. 983-1003, 1989.

[22] Nada D. \& Anastasia K. (2013) The role of social media in self-regulated learning. Retrieved May 14, 2013 from http://inderscience.metapress.com/ $\mathrm{m} 052277888 \mathrm{n} 7262 \mathrm{~m} /$

\section{ACKNOWLEDGMENT}

The authors acknowledge the support of the Suratpittaya School staff as well as University Sains Malaysia that has resulted in this article. 